\title{
PENDAPATAN PETANI DARI BUDIDAYA TANAMAN PURIK (Mitragyna sp) DI DESA NANGA MANDAY KECAMATAN BIKA KABUPATEN KAPUAS HULU
}

\author{
Farmer's Income From Purik Crops (Mitragyna sp) In Nanga Manday Village, District \\ Bika, Kapuas Hulu Regency
}

Hilaria Dita Oktaviani, Sudirman Muin, Gusti Hardiansyah

Fakultas Kehutanan Universitas Tanjungpura, Jalan Imam Bonjol Pontianak 78124

Email : hilariaditaoktaviani98@gmail.com

\begin{abstract}
Purik (Mitragyna sp), is one of the forestry plants that is currently cultivated and is the livelihood of the community, especially in Nanga Manday Village, Bika District, Kapuas Hulu Regency, when rubber prices dropped and fish catches were uncertain. The purpose of this study to answer how much the level of income, the value of the $R / C$ ratio, Break Ivent Point (BEP) of production and prices as well as the factors that affect the level of community income. The methodology used is observation and structured interviews. Based on data analysis, the community income from Purik cultivation is $R p$ $10,658 / \mathrm{kg}$ with an $R / C$ ratio of $3.6(>1)$ and the value of production BEP of $15.66 \mathrm{~kg}$ and the price BEP of Rp. 1,231/ kg. Based on the results of multiple linear regression analysis of income (profit) purik cultivation business as follows: $\hat{Y}=1.012-0.021 X 1+$ $0.000 X 2-0.0004 X 3+0.006 X 4-1.090 X 5-1.107 X 6-0.011 D$ with the results of the analysis determining the $R$ Square number is .986 (98\%).
\end{abstract}

Keywords: income, Nanga Manday, purik cultivation

\section{PENDAHULUAN}

Desa Nanga Manday merupakan salah satu desa yang ada di Kabupaten Kapuas Hulu yang terletak di Kecamatan Bika. Desa Nanga Manday memiliki dua dusun yaitu Dusun Tanjung Kapuas dan Dusun Palau. Sebagian besar masyarakat bermatapencaharian sebagai petani, nelayan, dan pedagang. Paling banyak ialah sebagai petani sebanyak 262 orang dan nelayan sebanyak 35 orang dari 315 orang penduduk Desa Nanga Manday (Monografi Desa Nanga Manaday, 2018).

Pekerjaan sebagai petani dan nelayan pada dasarnya banyak mengandung risiko dan ketidakpastian. Apalagi saat ini harga karet jauh merosot. Pada tahun 2010 harga karet di Desa Nanga Manday Kecamatan Bika Kabupaten Kapuas Hulu mencapai Rp $25.500 / \mathrm{kg}$ namun saat ini harga karet hanya sebesar Rp 6.000/kg. Menurut Imelda (2012) penghasilan dari tangkapan ikan bergantung pada kondisi alam, cuaca dan musim. Hal ini menyebabkan kehidupan perekonomian masyarakat Desa Nanga Manday tidak dapat dipastikan besar kecilnya pendapatan yang diperoleh. Akhir-akhir ini, masyarakat sangat terbantu dengan adanya purik yang memberikan penghasilan tambahan. Maka purik 
menjadi salah satu alternatif untuk pendapatan tambahan masyarakat.

Tanaman purik merupakan salah satu tanaman yang memiliki prospek sangat baik di Kabupaten Kapuas Hulu (Anita, dkk. 2019), khususnya bagi Desa Nanga Manday Kecamatan Bika, karena permintaan pasar akan kebutuhan purik berupa bahan mentah maupun barang jadi masih sangat besar, baik itu pasar lokal maupun pasar internasional. Permintaan ekspor dari Amerika dan eropa sekitar 1.000 ton (Portal Informasi Indonesia, 2020). Pendapatan petani yang diperoleh dari hasil tanaman purik dapat meningkatkan kesejahteraan hidup petani purik. Menurut Anita dkk. (2019) usaha tani purik banyak mempengaruhi masyarakat di Desa Sungai Uluk Palin, sehingga sebagian besar masyarakat berpindah usaha, dimana dulunya usaha tani karet sekarang berpindah ke usaha tani purik.

Data desa yang telah melaporkan jumlah petani purik dari 23 kecamatan di Kabupaten Kapuas Hulu pada tahun 2019 (Kumara, 2019), total perkiraan panen daun basah purik di wilayah Kabupaten Kapuas Hulu sebanyak 2.757,371 ton. Bila dihitung panen daun kering purik maka ada sebanyak 689,34275 ton dan jika panen dilakukan satu kali dalam satu bulan maka selama satu tahun Kabupaten Kapuas Hulu dapat menyumbang sebanyak 8.272,113 ton daun purik kering. Apabila harga purik masih tinggi sekitar 30.000/kg, Kabupaten Kapuas Hulu dapat memperoleh penerimaan sebesar 248.163.390.000 setiap tahunnya.

Sejauh ini, penelitian tentang analisis pendapatan sudah banyak dilakukan sebagai contohnya sudah dilakukan oleh Wonda dan Tomayahu (2016) serta Sridianto (2016). Kajian dari Wonda dan Tomayahu (2016) memberikan informasi pendapatan yang diterima petani kakao selama 1 tahun untuk luas lahan 0,5 hektar adalah Rp 1.150.556,- dan untuk luas lahan 1 hektar adalah Rp 2.662.500,- dengan nilai $\mathrm{R} / \mathrm{C}$ ratio untuk 0,5 hektar sebesar 3,38 dan nilai $\mathrm{R} / \mathrm{C}$ ratio untuk 1 hektar sebesar 5,18. Maka usaha tani Kakao berbasis masyarakat di Kelurahan Hinekombe Distrik Waibu Kabupaten Jayapura meskipun dengan luas lahan 0,5 hektar masih menguntungkan. Menurut Sridianto (2016) usaha tani tomat di Desa Kanreapia Kecamatan Tombolo Pao Kabupaten Gowa dapat meningkatkan pendapatan petani secara signifikan. Adapun jumlah pendapatan petani tomat adalah sebesar Rp14.324.938,34, dengan nilai dari R/C ratio sebesar 4,06 yang berarti bahwa setiap Rp. 1 yang dikeluarkan oleh petani tomat menghasilkan pendapatan sebesar Rp4,06 dapat disimpulkan bahwa usaha tersebut menguntungkan petani.

Adanya fluktuasi harga jual purik, penggunaan faktor produksi juga dapat mempengaruhi pendapatan di tingkat petani purik. Penggunaan faktor produksi seperti penggunaan sumber daya lahan, modal dan tenaga kerja perlu diperhatikan dalam proses 
produksi, agar tidak terjadi penggunaan yang berlebihan yang dapat merugikan petani dan menyebabkan tingkat produksi tidak optimal. Berdasarkan hal tersebut maka dilakukan penelitian dengan tujuan menguraikan besaran pendapatan, menilai kelayakan usaha budidaya tanaman purik, memperoleh nilai Break Event Point (BEP) dan mengidentifikasi faktor-faktor yang mempengaruhi pendapatan masyarakat dari usaha budidaya tanaman purik di Desa Nanga Manday Kecamatan Bika Kabupaten Kapuas Hulu.

\section{METODE PENELITIAN}

Penelitian ini dilaksanakan di Desa Nanga Manday Kecamatan Bika Kabupaten Kapuas Hulu dengan waktu \pm 4 (empat) minggu di lapangan. Objek penelitian adalah masyarakat (Kepala Keluarga) Dusun Palau dan Dusun Tanjung Kapuas Desa Nanga Manday Kecamatan Bika Kabupaten Kepuas Hulu yang membudiadayakan tanaman purik. Alat yang digunakan dalam penelitian ini berupa kamer, kuesioner, kalkulator, program Microsoft Excel dan program SPPS.

Penentuan jumlah sampel penelitian menggunakan rumus Slovin (1960) seperti berikut:

$\mathrm{n}=\frac{N}{1+N(e)^{2}}$

Dimana:

$\mathrm{n}=$ ukuran sampel/jumlah sampel yang diambil

$\mathrm{N}=$ ukuran populasi

e $=\operatorname{error}(10 \%)$

Hasil perhitungan dengan rumus Slovin (1960) dari 129 KK ada sebanyak 56 KK yang dijadikan responden penelitian. Penetukan jumlah sampel masing-masing dusun yakni Dusun Palau dan Dusun Tanjung Kapuas ditentukan dengan menggunakan metode stratifikasi berimbang dengan rumus Teken (1965) sebagai berikut.

$\mathrm{nh}=\frac{N h}{N} \times n$

\section{Keterangan:}

$\mathrm{nh}=$ jumlah responden yang diambil dalam 1 (satu) dusun

$\mathrm{Nh}=$ jumlah KK dalam 1 dusun

$\mathrm{n} \quad=$ jumlah responden yang diambil

$\mathrm{N}=$ jumlah KK dalam 1 desa

Berdasarkan hasil perhitungan dengan Rumus Teken (1965) diperoleh jumlah sampel penelitian untuk Dusun Palau sebanyak 26 KK dan Dusun Tanjung Kapuas sebanyak 30 KK.

Jenis penelitian dan data yang disajikan diperoleh dari sumber-sumber data yang meliputi sumber data primer dan sumber data sekunder. Teknik pengumpulan data dalam rencana penelitian ini digunakan teknik observasi dan wawancara terstruktur.

Pendapatan usaha budidaya tanaman purik dapat dirumuskan sebagai berikut: $\mathrm{Pd}=\mathrm{TR}-\mathrm{TC}$

Dimana :

Pd : Pendapatan usaha budiadaya tanaman purik $(\mathrm{Rp} / \mathrm{kg})$

TR : Rata-rata penerimaan penjualan daun purik $(\mathrm{Rp} / \mathrm{kg})$

TC : Rata-rata biaya produksi purik yang dikeluarkan (Rp/kg).

Analisis R/C ratio (Return Cost Ratio) (Soekartawi, 1994) dengan rumus:

$\mathrm{a}=\mathrm{R} / \mathrm{C}$

Adapun rumus BEP yang digunakan adalah sebagai berikut (Rahardi, 2003):

$B E P($ produksi $)=\frac{T C}{P}$ 
$B E P($ harga $)=\frac{T C}{Q}$

Dimana :

TC : Total Cost/Total Biaya (Rp)

$\mathrm{P} \quad$ : Price/Harga (Rp)

Q : Quantita/produksi (kg)
Analisis faktor yang mempengaruhi pendapatan budidaya purik digunakan persamaan fungsi keuntungan CobbDouglas tersebut ditransformasikan ke dalam bentuk double logaritma natural (ln), sehingga merupakan bentuk regresi linear berganda sebagai berikut.

$\ln \pi=\ln A+\beta_{1} \ln X_{1}+\beta_{2} \ln X_{2}+\beta_{3} \ln X_{3}+\beta_{4} \ln X_{4}+\beta_{5} \ln X_{5}+\beta_{6} \ln X_{6}+\delta_{1} D_{1}+\mu$

Keterangan:

$\pi$ : Keuntungan yang dinormalkan $\left(\mathrm{X}_{4}\right.$,

$\mathrm{X}_{5}$ dan $\mathrm{X}_{6}$ ) dengan harga daun purik

$(\mathrm{Rp} / \mathrm{kg})$

A : Intersep

$\mathrm{X}_{1}$ : Jumlah tanaman purik yang

dibudidayakan (phn)

$\mathrm{X}_{2}$ : Umur tanaman purik (th)

$\mathrm{X}_{3}$ : Tenaga Kerja (HOK)

$\mathrm{X}_{4}$ : Harga bibit yang dinormalkan dengan harga (Rp)

$\mathrm{X}_{5}$ : Biaya pupuk yang dinormalkan dengan harga $(\mathrm{Rp})$

$\mathrm{X}_{6}$ : Upah tenaga kerja yang dinormalkan dengan harga (Rp)

$\mathrm{D}$ (Dummy) : Jenis daun purik yang dijual

$\mathrm{D}_{1} \quad$ : Daun basah (bobot 1).
$\mathrm{D}_{2} \quad$ : Daun remah kering (bobot 2).

$B_{\mathrm{i}}$ : Koefisien regresi variabel $\mathrm{X}_{\mathrm{i}}$

$\delta$ : Koefisien regresi variabel $\mathrm{D}$

(Dummy) : daun basah atau daun remahan kering

$\mu \quad$ : Kesalahan (error)

\section{HASIL DAN PEMBAHASAN}

Identitas Responden

Hasil wawancara terhadap 56 responden yang membudidaya tanaman purik di Desa Nanga Manday Kecamatan Bika Kabupaten Kapuas Hulu diperoleh identitas responden berdasarkan usia responden, tingkat pendidikan dan jumlah anggota keluarga sebagai berikut :

Tabel 1. Identitas Responden Berdasarkan Usia Responden, Tingkat Pendidikan dan Jumlah Anggota Keluarga (Respondent identity based on the age of the respondent, level of education, and number of family members)

\begin{tabular}{llll}
\hline Identitas Responden & & $\begin{array}{l}\text { Jumlah } \\
\text { Responden } \\
\text { (Orang) }\end{array}$ & $\begin{array}{l}\text { Persentase } \\
(\%)\end{array}$ \\
\hline Usia Responden & a. < 15 tahun & 0 & 0 \\
& b. 15 - 64 tahun & 51 & 91,07 \\
& c. $>65$ tahun & 5 & 8,93 \\
\hline Pendidikan & a. Tidak sekolah dan SD & 44 & 79 \\
& b. SMP/SLTP & 9 & 16 \\
& c. SMA/SLTA & 3 & 5 \\
\hline Jumlah Anggota Keluarga & a. 1 - 3 orang & 24 & 43 \\
& b. 4 -6 orang & 29 & 52 \\
& c. $>7$ orang & 3 & 5 \\
\hline
\end{tabular}




\section{Usia Responden}

Usia Produktif menurut UndangUndang Tenaga Kerja, yaitu mereka yang berada di antara 15 tahun sampai dengan 64 tahun. Berdasarkan hal tersebut maka dari 56 responden, yang termasuk ke dalam tenaga kerja usia produktif ada sebanyak 51 responden dengan persentase $91,07 \%$. Hal ini menunjukkan usia kerja petani purik paling banyak ialah usia produktif.

\section{Pendidikan Formal}

Pada umumnya pendidikan seseorang dapat mempengaruhi tingkat pendapatan yang diterimanya, namun dengan perkembangan teknologi dan komunikasi pada saat ini membuat masyarakat cukup kreatif dan inovatif dalam menjalani suatu usaha. Begitu juga yang dialami masyarakat di Desa Nanga Manday. Hal ini sejalan dengan yang dikemukakan Juliansyah dan Riyono (2018) variabel tingkat pendidikan tidak signifikan namun berpengaruh secara positif terhadap pendapatan petani karet di Desa Bukit Hagu Kecamatan Lhoksukon Kabupaten Aceh Utara.

\section{Jumlah Anggota Keluarga}

Jumlah anggota keluarga sangat menentukan besar kecilnya pengeluaran rumah tangga. Biasanya semakin banyak jumlah anggota keluarga maka akan semakin besar jumlah pengeluran dan sebaliknya. Namun di sisi lain, jumlah anggota kelurga yang banyak juga sangat membantu dalam tersediannya tenaga kerja untuk kegiatan budidaya purik. Sehingga biaya untuk mengupah tenaga kerja di luar kelurga dapat diperkecil. Hal ini sejalan dengan Suratman (2015) yang mana persentase curahan tenaga kerja dalam keluarga terhadap jumlah keseluruhan tenaga kerja pada usaha tani terong adalah $86,11 \%$, ini berarti tenaga kerja dalam keluarga mendominasi kegiatan pada usaha tani terong, sisanya $13,89 \%$ kegiatan usaha tani terong ini dilaksanakan oleh tenaga kerja luar keluarga.

\section{Kegiatan Budidaya Purik}

Budidaya purik pada tahap pertama ialah penyemaian bibit. Penyemaian bibit dilakukan dalam suatu wadah, kemudian disapih ke tiap-tiap gelas plastik. Tanaman dapat disapih apabila mencapai tinggi 1-2 cm. Biasanya masyarakat menggunakan gelas bekas Aqua dan gelas sejenis lainnya. Media yang digunakan yaitu tanah tepi sungai yang becek, kondidinya dapat dilihat pada Gambar 1 bagain a. Bibit siap tanam ke lapangan dengan usia tanaman 5-6 bulan dengan tinggi $10-20 \mathrm{~cm}$. Masyarak tidak hanya menanam di kebun pribadi, tetapi juga ada yang menanam purik di tanah pinggiran sungai dekat tempat tinggalnya. Oleh karena itu, tanaman purik sangat mudah dijumpai di pinggiran jalan dan di pinggiran sungai.

Kegiatan pemeliharaan purik tidak rumit, hanya membutuhkan pupuk dan insektisida. Biasa masyarakat menggunakan pupuk urea dan pupuk kompleks, sementara insektisida biasanya masyarakat menggunkan matador, lanit dan gandasil. Pemupukan dan pemberian insektisida biasanya dilarutkan dalam air kemudian disemprot pada tanamanan. 


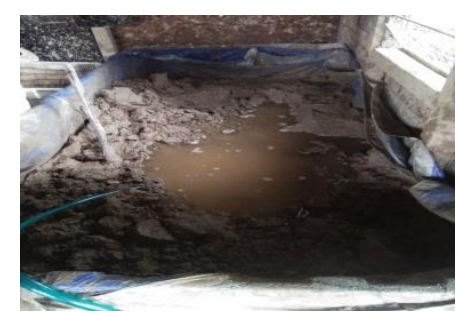

a

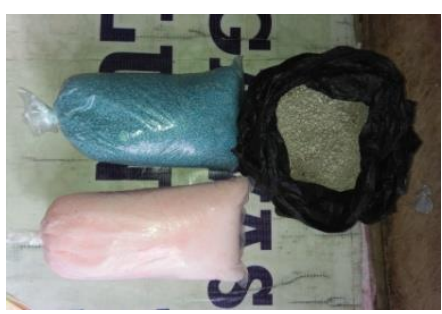

b

Gambar 1. Media penanaman semai dan bibit purik (a) dan pupuk (b) (Media for planting seedlings and purik seedlings (a) and fertilizer (b))

Tahapan Pemanenan sampai Pengolahan Purik

Pemanenan pertama dapat dilakukan apabila bibit telah berusia 3-6 bulan. Alat-alat yang masyarakat gunakan dalam kegiatan pemanenan biayanya berupa karung goni, raga, parang dan tengkalang. Tengkalang memiliki bentuk yang sama dengan "tengken" hanya saja masyarakat di Desa Nanga Manday membuat tubuhnya sebagian besar dari plastik bukan rotan dapat di lihat pada Gambar 2. Di desa ini tidak semua orang mengupah panen tetapi juga sebagian besar menggunkan anggota keluarga dan ada juga istilah "beambik hari". Beambik hari merupakan kegiatan untuk membantu orang lain yang kemudia di hari-hari selanjutnya, orang yang tadi di bantu dalam kegiatannya kembali membantu orang yang telah membatunya.

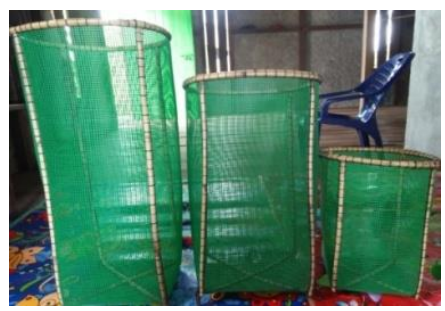

Gambar 2. Tengkalang (Tengkalang)

Setelah kegiatanan pemanenan, dilanjutkan dengan pasca panen. Masyarakat tidak hanya memjual purik dalam bentuk remahan tetapi ada juga daun basah. Purik yang di jual dalam keadaan basah tidak perlu kegiatan lanjutan, langsung saja di jual. Sementara bagi petani yang menjual dalam bentuk kering atau lebih dikenal dengan kata "remahan" memiliki proses yang cukup panjang. Dimulai dengan menjemur daun sampai benar-benar kering, biasanya membutuhkan 2-3 hari dengan cuaca panas terik. Alat yg masyarakat gunakan untuk menjemur ialah waren, terpal dan ada juga dari karung semen yang kemudian dijahit menjadi satu. Setelah kering maka daun harus langsung di mesin dengan mesin penggiling atau dengan cara tradisional yaitu digosok dengan tangan. Alat yang digunakan untuk menggosok ini 
biasanya raga dan ada juga alat yang dibuat dari kayu kemudian bagian atasnya diberi waren. Remahan kemudian di tampi menggunakan tamoah atau nyiu yang biasanya lebih dikenal masyarakat dengan sebutan "capan", tujuannya supaya remahan bersih dari tulang-tulang daun utama. Berikut ini merupakan serangkaian kegiatan pengolahan purik:

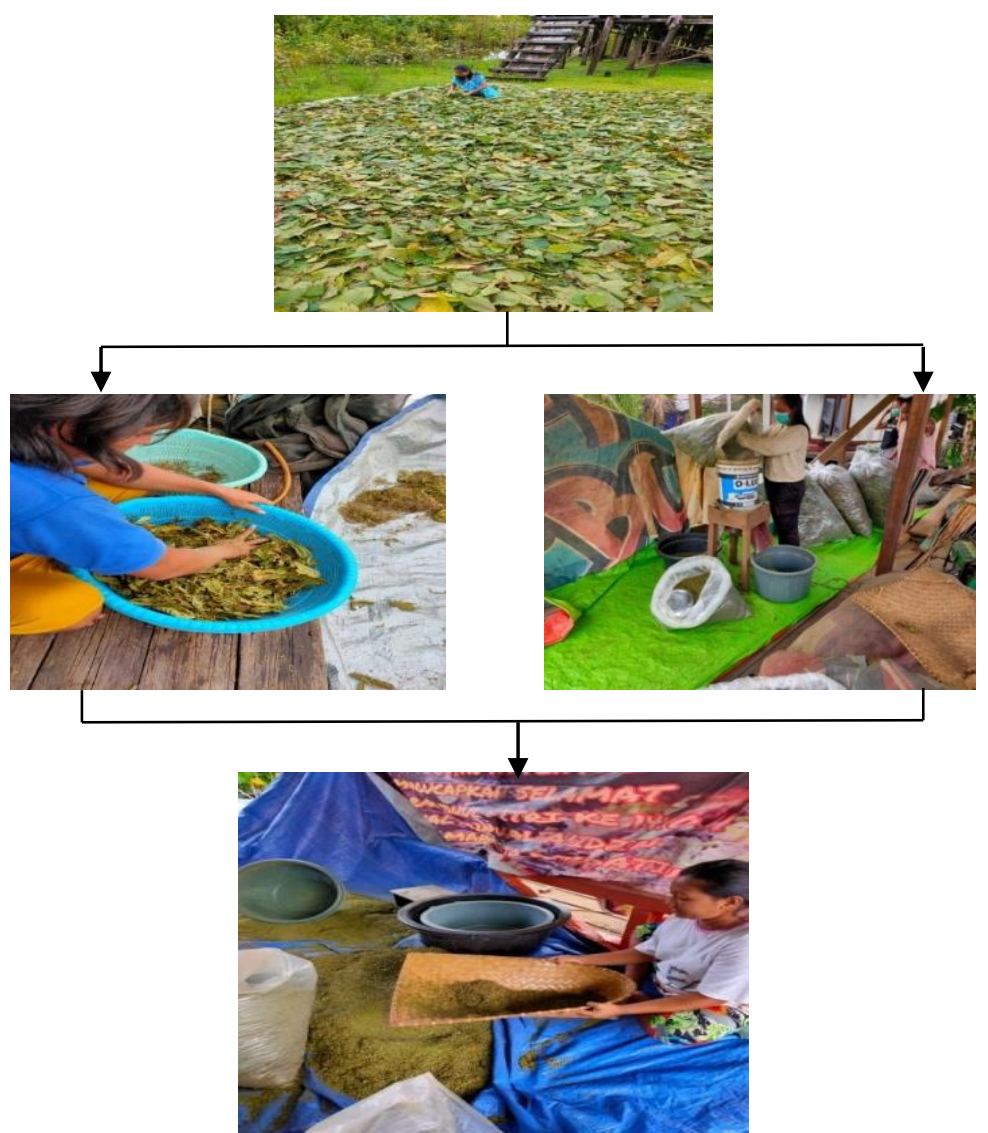

\section{Gambar 3. Rangkaian Kegiatan Pengolahan Purik (Series of Purik Processing Activities)}

Keterangan :

Gambar bagian atas : penjemuran purik, gambar bagian kiri : penggosokan daun purik, gambar bagian kanan : penggilinggan daun purik dan gambar bagian bawah : menampi

\section{Pendapatan Usaha Budidaya Purik}

Pendapatan petani purik adalah pendapatan yang diperhitungkan dari usaha budidaya purik yakni merupakan selisih antara penerimaan usaha budidaya purik dengan biaya produksi, yang dapat menunjukkan tingkat keuntungan usaha budidaya purik.
Pendapatan petani purik (Mitragyna $\mathrm{sp}$ ) ini dihitung menurut Soekartawi (2002) dengan rumus $\pi=$ Y.Py $-\sum \mathrm{X}_{\mathrm{i} .} \mathrm{PX}_{\mathrm{i} .}$ dan dalam penelitian ini parameter diukur dalam satuan Rupiah per kilogram purik yang diproduksi/dijual.

Selama usaha budidaya purik (Mitragyna sp), petani menggunakan 
input faktor produksi yang meliputi pupuk, insektisida, BBM, dan peralatan yang masa pakainya tidak sampai satu tahun dalam usaha budidaya purik (Mitragyna sp). Penerimaaan usaha budidaya purik merupakan nilai yang diperoleh dari setiap kilogram produksi purik dikalikan dengan harga jual yang merupakan pendapatan kotor karena belum dikurangi biaya-biaya yang dikeluarkan setiap kilogram produksi purik. Rata-rata penerimaan, biaya yang dikeluarkan dikeluarkan setiap kilogram purik yang diproduksi dan pendapatan yang diperoleh masyarakat seperti pada Tabel 2.

Tabel 2. Penerimaan, Biaya dan Pendapatan dari Hasil Budidaya Tanaman Purik (Revenues, Costs and Revenue from Purik Crop Cultivation Results)

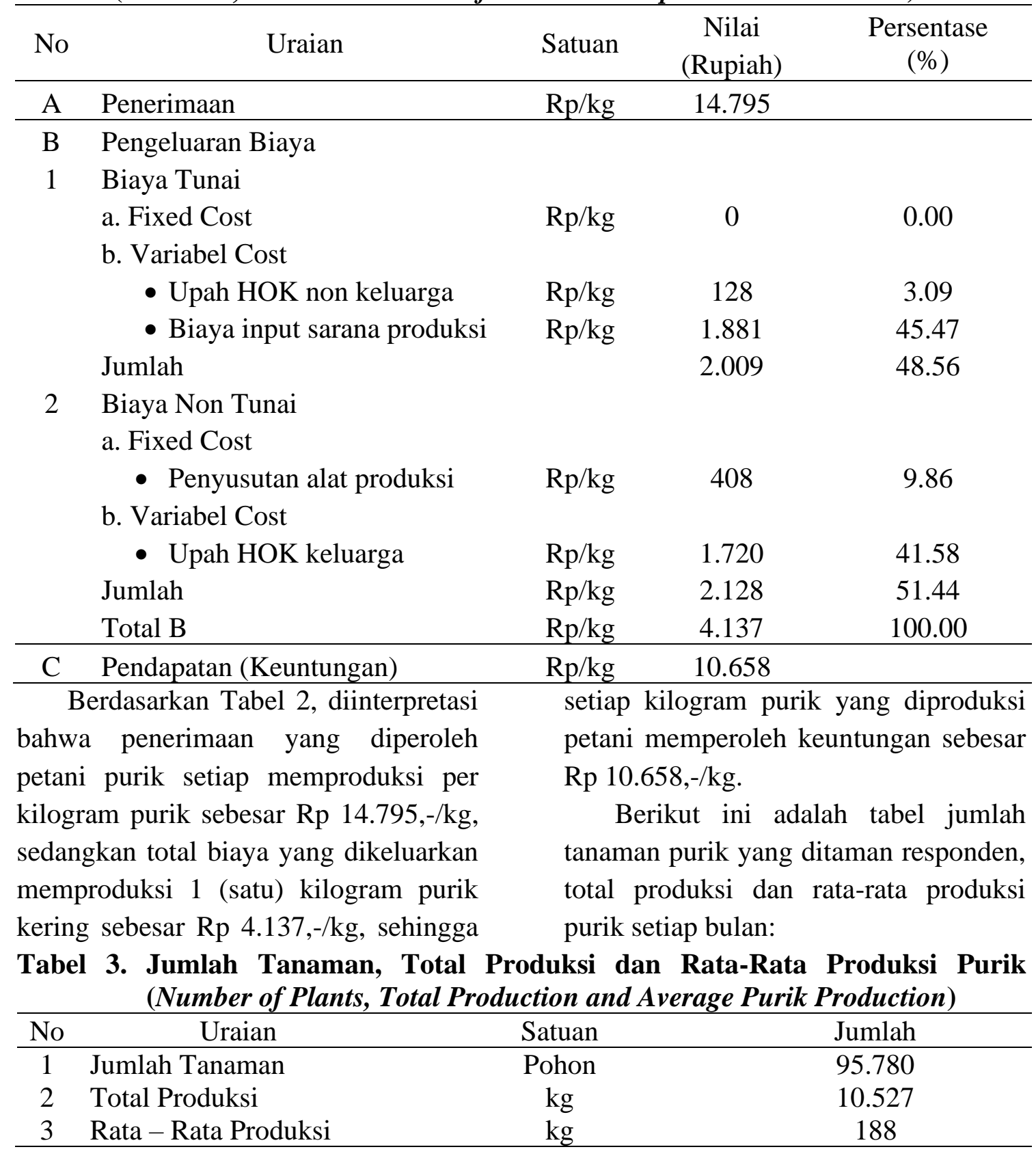


Berdasarkan hasil observasi pengamatan lapangan diperoleh informasi dari responden penelitian bahwa rata-rata setiap bulannya produksi purik sebesar $188 \mathrm{~kg}$. Mengacu hasil analisis pendapatan (keuntungan) yang diperoleh petani purik setiap produksi 1 (satu) kilogram purik sebesar Rp 10.658,- maka setiap bulannya petani purik akan memperoleh pendapatan (keuntungan) sebesar $\mathrm{Rp}$ 2.003.704,-/bulan atau dalam waktu setahun sebesar Rp 24.044.448,-/tahun. Apabila tiap masyarakat di Desa Nanga Manday memproduksi sebanyak 188 $\mathrm{Kg}$ dengan keuntungan $\mathrm{Rp} 10.658 / \mathrm{Kg}$ maka bila ada 56 orang, keuntungannya sebesar Rp 112.207.424,-/bulan atau Rp 1.346.489.088,-/tahun.

Keuntungan dari hasil budidaya purik sebesar Rp 2.003.704,-/bulan, menunjukkan angka yang lebih kecil bila dibandingkan dengan upah minimum kabupaten/kota (UMK) Kalimantan Barat 2020 khususnya Kabupaten Kapuas Hulu yaitu sebesar Rp 2.483.000,-/bulan. Namun, pendapatan dari hasil budidaya purik memberikan kontribusi sebesar $81 \%$. Maka budidaya purik sangat efektif untuk dijadikan alternatif pendapatan tambahan masyarakat.
Total perkiraan panen daun basah Kabupaten Kapuas Hulu data sampai dengan 12 Agustus tahun 2019 tercatat ada sebanyak $2.757 .371 \mathrm{Kg}$ atau 2.757,371 ton. Data tersebut diperoleh dari 23 kecamatan yang ada di Kabupaten Kapuas Hulu, salah satunya ialah Kecamatan Bika dimana tercatat bahwa Kecamatan Bika menyumbang sebanyak $13.600 \mathrm{~kg}$ atau sebanyak 13,6 ton. Dari hasil penelitian, jumlah total panen daun basah di Desa Nanga Manday Kecamatan Bika ada sebanyak $31.203 \mathrm{~kg}$ atau 31,203 ton dalam 1 bulan. Bila dihitung jumlah uang yang beredar dengan biasanya masyarakat menjual daun basah Rp 4000/Kg maka paling tidak ada sebanyak Rp 124.812.000 uang yang beredar di Desa Nanga Manday. Angkat ini menunjukkan 2,29 kali lipat lebih besar dari data desa-desa yang telah melaporkan jumlah petani purik di wilayahnya. Artinya Desa Nanga Manday dapat menyumbang sebanyak $1,13 \%$ dari total panen basah di Kabupaten Kapuas Hulu. Pada gambar berikut dapat dilihat jelas total perkiraan panen daun basah pada 23 kecamatan di Kabupaten Kapuas Hulu: 


\begin{tabular}{|c|c|c|c|c|c|c|}
\hline NO & KECAMATAN & $\begin{array}{l}\text { JML DESA/KEL } \\
\text { YANG MELAPOR }\end{array}$ & $\begin{array}{c}\text { JML PETANI } \\
\text { ( ORANG ) }\end{array}$ & $\begin{array}{l}\text { TOTAL POHON DITANAM } \\
\text { ( BATANG ) }\end{array}$ & $\begin{array}{c}\text { TOTAL LUAS LAHAN } \\
\text { ( HEKTAR ) }\end{array}$ & $\begin{array}{l}\text { TOTAL PERKIRAAN PANEN DAUN BASAH } \\
\qquad(\mathrm{KG})\end{array}$ \\
\hline 1. & PUTUSSIBAU UTARA & 10 & $1,011.00$ & $497,720.00$ & 569.88 & $101,368.00$ \\
\hline 2. & BIKA & 1 & 48.00 & $54,400.00$ & 34.00 & $13,600.00$ \\
\hline 3. & EMBALOH HILIR & 9 & $1,526.00$ & $1,408,240.00$ & $1,437.50$ & $442,356.00$ \\
\hline 4. & EMBALOH HULU & 5 & 773.00 & $420,896.00$ & 302.88 & $38,746.00$ \\
\hline 5. & BUNUT HILIR & 7 & $1,243.00$ & $1,303,474.00$ & 897.23 & $220,879.00$ \\
\hline 6. & BUNUT HULU & 1 & 80.00 & $20,450.00$ & 48.00 & $12,000.00$ \\
\hline 7. & JONGKONG & 0 & - & - & - & - \\
\hline 8. & HULU GURUNG & 3 & 324.00 & $200,000.00$ & 192.00 & $23,000.00$ \\
\hline 9. & SELIMBAU & 2 & 311.00 & $100,000.00$ & 100.00 & $14,500.00$ \\
\hline 10. & SEMITAU & 0 & - & - & - & - \\
\hline 11. & SEBERUANG & 0 & - & - & - & - \\
\hline 12. & BATANG LUPAR & 8 & 383.00 & $81,029.00$ & 110.13 & $8,465.00$ \\
\hline 13. & EMPANANG & 0 & - & - & - & - \\
\hline 14. & BADAU & 0 & - & - & - & - \\
\hline 15. & SILAT HILIR & 0 & - & - & - & - \\
\hline 16. & SILAT HULU & 0 & - & - & - & - \\
\hline 17. & PUTUSSIBAU SELATAN & 13 & $3,303.00$ & $2,656,900.00$ & $1,686.00$ & $1,686,000.00$ \\
\hline 18. & KALIS & 2 & 526.00 & $1,213,435.00$ & 392.00 & $139,984.00$ \\
\hline 19. & BOYAN TANJUNG & 5 & 428.00 & $252,750.00$ & 220.60 & $19,635.00$ \\
\hline 20. & MENTEBAH & 4 & 664.00 & $506,900.00$ & 186.90 & $30,358.00$ \\
\hline 21. & PENGKADAN & 0 & - & - & - & - \\
\hline 22. & SUHAID & 4 & 127.00 & $74,211.00$ & 59.35 & $6,480.00$ \\
\hline \multirow[t]{2}{*}{23.} & PURING KENCANA & 0 & - & - & - & - \\
\hline & JUMLAH & 74 & $10,747.00$ & $8,790,405.00$ & $6,236.47$ & $2,757,371.00$ \\
\hline
\end{tabular}

Gambar 4. Data-data yang Telah Melaporkan Jumlah Petani Purik di Wilayahnya (Data sampai dengan 12 Agustus 2019) (Data that Has Reported the Number of Purik Farmers in the Area (Data up to 12 August 2019)

\section{Kelayakan Usaha Budidaya Purik}

Kelayakan usaha budidaya purik dianalisis menggunakan analisis $\mathrm{R} / \mathrm{C}$ ratio yakni analisis kelayakan jangka pendek. Hasil analisis kelayakan jangka pendek ( $\mathrm{R} / \mathrm{C}$ rasio) usaha budidaya kratom seperti diuraikan pada Tabel 4.

Tabel 4. Analisis Kelayakan Usaha Budidaya Purik (Analisis R/C Ratio) (Feasibility Analysis of Purik Cultivation (R / C Ratio Analysis))

\begin{tabular}{llllc}
\hline No & & Uraian & Satuan & Jumlah \\
\hline A & Penerimaan & Rp/kg & 14.795 \\
B & Total Biaya & Rp/kg & 4.137 \\
C & R/C ratio & & 3,6 \\
\hline
\end{tabular}

Nilai $\mathrm{R} / \mathrm{C}$ rasio usaha budidaya purik sebesar 3,6 lebih besar dari 1 (satu), sehingga disimpulkan bahwa usaha budidaya purik layak diusahakan. Nilai R/C ratio sebesar 3,6 atau lebih besar dari satu, menunjukkan setiap rupiah yang dikeluarkan dapat menghasilkan pendapatan sebesar 3,6 rupiah atau keuntungan yang diterima besarnya 3,6 kali lipat dari 1 rupiah yang dikeluarkan.

Bila dibandingkan dengan hasil analisis $\mathrm{R} / \mathrm{C}$ rasio dalam penelitian
Junaidi (2016) pada usaha tani kelapa sawit di Desa Panton Pange Kecamatan Tripa Makmur Kabupaten Nagan Raya sebesar 2,86 . Artinya setiap biaya yang dikeluarkan sebesar satu satuan rupiah Rp. 1,- akan menghasilkan penerimaan sebesar Rp. 2,86,- sehingga usaha mendapatkan keuntungan. Usaha budidaya purik sama-sama menguntungkan dengan usaha tani kelapa sawit, namun usaha budidaya purik memiliki tingkat kelayakan yang 
lebih tinggi $74 \%$ dibanding dengan usaha tani kelapa sawit.

\section{Break Event Point (BEP) Usaha Budidaya Purik}

Analisis BEP digunakan untuk mengetahui berapa banyak jumlah produksi purik dengan tingkat harga yang mesti dijual supaya petani di Desa Nanga Manday Kecamatan Bika Kabupaten Kapuas Hulu memperoleh keuntungan dari budidaya tersebut. Total produksi purik dari 56 responden sebesar $10.527 \mathrm{~kg}$ atau rata-rata produksi per bulan sebesar $188 \mathrm{~kg}$, dengan total biaya produksi sebesar Rp 231.651,- dan rata-rata harga per kilogram purik Rp 14.795,-/kg.
BEP Produksi dan BEP harga memiliki rumus sebagai berikut:

$$
\begin{gathered}
\mathrm{BEP}(\text { Produksi })=\frac{\mathrm{TC}}{\mathrm{P}}=\frac{\mathrm{Rp} 231.561 / \mathrm{Kg}}{\mathrm{Rp} 14.795}= \\
15,65 \mathrm{Kg} \\
\mathrm{BEP}(\text { Harga })=\frac{\mathrm{TC}}{\mathrm{Q}}=\frac{\mathrm{Rp} 231.561 / \mathrm{Kg}}{188 \mathrm{Kg}}=\mathrm{Rp} \\
1.231,-
\end{gathered}
$$

Artinya untuk memperoleh keuntungan maka masyarakat yang membudidaya purik harus menjual purik diatas harga $\mathrm{Rp} 1.231,-$, dengan jumlah produksi diatas $15,65 \mathrm{~kg}$.

Di bawah ini dapat dilihat grafik yang menggambarkan tingkat harga jual per kilogram kartom di Desa Nanga Manday Kecamatan Bika Kabupaten Kapuas Hulu:

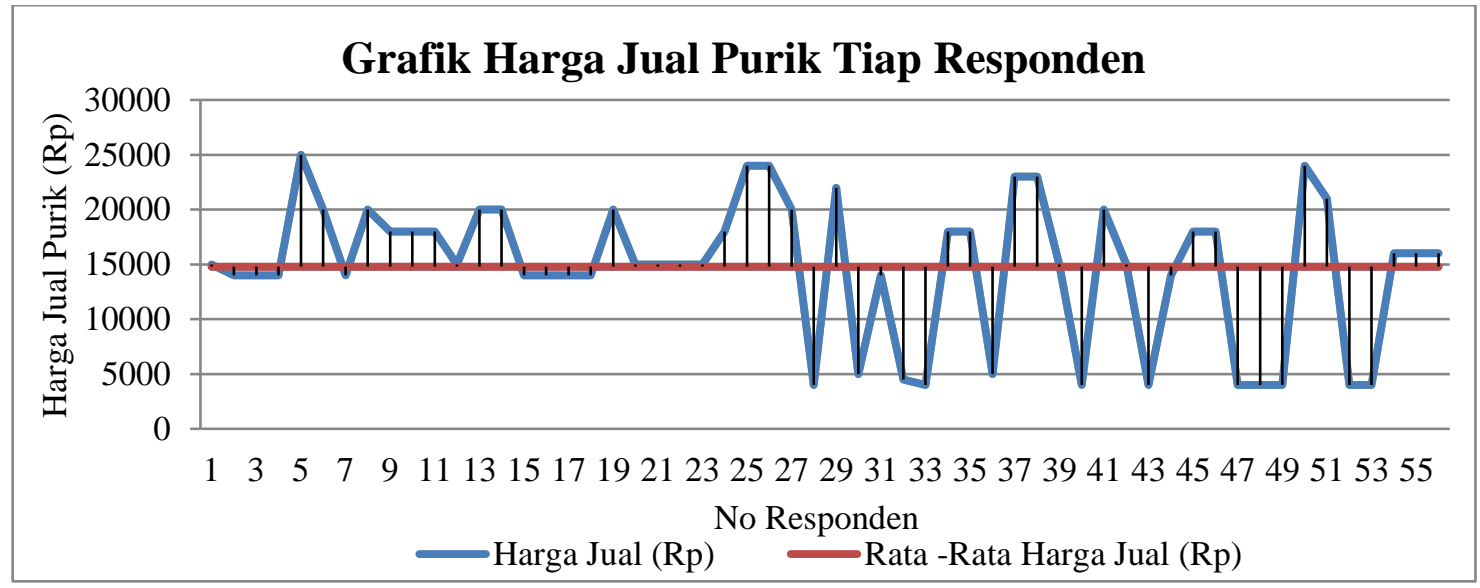

Gambar 5. Grafik Harga Jual Purik Tiap Responden (Graph of the Purik Selling Price of Each Respondent)

Petani yang menjual purik dalam keadaan basah memiliki harga jual sebesar Rp 4.000/kg - Rp 5.000/kg dan purik dalam keadaan kering memiliki harga jual sebesar Rp 14.000/kg - Rp $25.000 / \mathrm{kg}$. Selain jenis daun purik yang dijual, harga beli yang diterima petani dari setiap pengumpul dan waktu penjualan purik juga menjadi salah satu penyebab harga jual yang berfluktuasi.
Hal inilah yang menyebabkan harga jual bila dilihat dari grafik sangat bervariasi.

Faktor-Faktor yang Mempengaruhi Pendapatan Usaha Budidaya Purik

Analisis faktor-faktor yang diduga berpengaruh terhadap pendapatan usaha budidaya purik dilakukan dengan Uji statistik Parametrik menurut persamaan fungsi keuntungan Cobb-Douglas yang ditransformasi ke bentuk logaritma natural (ln) terdiri 1 (satu) variable 
terikat yakni tingkat pendapatan usaha budidaya purik, dan 7 (tujuh) varibel bebas sebagai berikut : (a) Jumlah tanaman purik $\left(\mathrm{X}_{1}\right)$, (b) Umur tanaman purik $\left(\mathrm{X}_{2}\right)$, (c) Tenaga Kerja/HOK $\left(\mathrm{X}_{3}\right)$, (d) Harga bibit purik (X4), (e) Cost Input produksi ( $\mathrm{X}_{5}$ ), (f) Upah $\mathrm{HOK}$ ( $\mathrm{X}_{6}$ ), dan (g) Dummy (D).

Salah satu persyaratan uji statistik parametrik (Regresi) adalah model regresi tersebut sudah memenuhi kriteria Best Unbiased Estimator (BLUE), sehingga dalam penelitian ini dilakukan beberapa uji evaluasi ekonomietri terdiri: (a) Uji Normalitas
Data, (b) Uji Multikolinearitas, (c) Uji Heteroskedaastisitas dan (d) Uji Autokorelasi.

Setelah dilakukan uji model regresi dan diketahui bahwa model regresi tersebut sudah memenuhi kriteria Best Unbiased Estimator (BLUE), selanjutnya dilakukan analisis faktorfaktor yang diduga mempengaruhi pendapatan usaha budidaya purik. Hasil analisis regresi linear berganda faktor yang mempengaruhi pendapatan usaha budidaya purik seperti tertera pada Tabel 5.

Tabel 5. Hasil Analsisi Regresi Linear Berganda Faktor Yang Mempengaruhi Pendapatan Usaha Budidaya Purik (Results of Multiple Linear Regression Analysis Factors Affecting Purik's Cultivation Business Income)

\begin{tabular}{llcccc}
\hline \multirow{2}{*}{ No } & \multirow{2}{*}{ Variabel } & \multicolumn{2}{c}{ Unstandardized Coefficients } & \multirow{2}{*}{$\mathrm{t}$} & \multirow{2}{*}{ sig } \\
\cline { 3 - 4 } & & $\beta$ & std error & & \\
\hline 1 & (Constant) & 1,012 & 0.029 & 35,213 & 0,000 \\
2 & Jumah Tanaman (X1) & $-0,021$ & 0,000 & $-0,566$ & 0,574 \\
3 & Umur Tanaman (X2) & 0,000 & 0,000 & 1,404 & 0,167 \\
4 & TK HOK (X3) & $-0,0004$ & 0,000 & $-0,281$ & 0,780 \\
5 & Harga bibit (X4) & 0,006 & 0,018 & 0,328 & 0,744 \\
6 & Input produksi (X5) & $-1,090$ & 0,042 & $-25,796^{* *}$ & 0,000 \\
7 & Upah HOK (X6) & $-1,107$ & 0,036 & $-30,718^{* *}$ & 0,000 \\
8 & Dummy (D) & $-0,011$ & 0,012 & $-0,910$ & 0,367 \\
\hline $\mathrm{R}=0,993^{\mathrm{a}}, \mathrm{R}$ Square $=0,986, \mathrm{~F}=484,961$, Siq $=0,000^{\mathrm{a}}$ & & \\
\hline
\end{tabular}

Berdasarkan hasil analisis regresi linear berganda diperoleh fungsi pendapatan (keuntungan) usaha budidaya purik sebagai berikut:

\begin{tabular}{|c|c|}
\hline \multicolumn{2}{|c|}{$\hat{\mathbf{Y}}=1,012-0,021 X_{1}+0,000 X_{2}-0,0004 X_{3}+0,006 X_{4}-1,090 X_{5}-1,107 X_{6}-0,011 D$} \\
\hline $\begin{array}{l}\text { Konstanta sebesar } 1,012 \text {, artinya } \\
\text { jika variabel bebas }(\mathrm{Xi}) \text { nilainya adalah }\end{array}$ & $\begin{array}{l}\text { terhadap variabel terikat }(\hat{Y}) \text { sebesar } \\
98,6 \% \text {, sedangkan sisanya sebesar } 1,4 \%\end{array}$ \\
\hline nol (0), maka pendapatan (keuntungan) & merupakan \\
\hline usaha budidaya purik $(\hat{Y})$ nilainya & dipengaruhi oleh varibel lain yang tidak \\
\hline adalah $\mathrm{Rp} 1,012,-/ \mathrm{kg}$. Hasil analisis & dimasukan dalam model \\
\hline determinasi diperoleh angka $\mathrm{R}$ Squa & seperti \\
\hline sebesar $0,986 \quad(98,6 \%), \quad$ hal ini & Masyarakat ada yang membudidayakan \\
\hline $\begin{array}{l}\text { menunjukkan bahwa peresentase } \\
\text { sumbangan pengaruh varibel bebas }\left(\mathrm{X}_{\mathrm{i}}\right)\end{array}$ & $\begin{array}{l}\text { purik di tepi sungai dan ada juga yang } \\
\text { membudidayakan purik cukup jauh dari }\end{array}$ \\
\hline
\end{tabular}


sungai. Air sungai membawa unsur hara yang terhanyut akibat erosi, kemudian lambat laun akan mengendap dan mengakibatkan tanah di tepi sungai biasanya menjadi subur. Tanah yang subur sangat menguntungkan bagi petani purik. Hal inilah yang tidak diuji pada penelitian ini sehingga masih ada $1,4 \%$ menjadi error.

Hasil uji koefisien regresi secara bersama-sama (Uji F) diketahui nilai $\mathrm{Sig}=0,000$, artinya variabel bebas $\left(\mathrm{X}_{\mathrm{i}}\right)$ secara bersama berpengaruh signifikan terhadap variabel terikat ( $\hat{Y})$ yakni pendapatan usaha budidaya purik.

Pengaruh Jumlah Tanaman Purik Terhadap Pendapatan Usaha Budidaya Purik

Berdasarkan hasil observasi lapangan, diketahui bahwa kegiatan pemupukan tanaman, upaya perlindungan dari hama dan penyakit, serta kegiatan pembersihan lahan purik hanya sebagian kecil dilakukan responden penelitian yang membudidayakan purik. Hal ini menyebabkan jumlah tanaman purik tidak berpengaruh signifikan terhadap pendapatan (keuntungan) usaha budidaya purik.

Penambahan jumlah tanaman akan menambah jumlah biaya yang dikeluarkan untuk kegiatan pemeliharaan agar produksi daun yang dihasilkan lebih besar dan kualitas daunnya baik, seperti kegiatan pemupukan dan pemeliharaan dari hama dan penyakit. Jika penambahan jumlah tanaman purik tersebut tidak diikuti dengan kegiatan pemeliharaan yang efektif, sehingga tidak mampu meningkatkan penerimaaan (produksi), sementara biaya yang dikeluarkan bertambah maka pendapatan (keuntungan) akan menurun. Hal ini sesuai teori ekonomitrika bahwa penambahan biaya produksi akan menurunkan keuntungan.

\section{Pengaruh Umur Tanaman Purik Terhadap Pendapatan Usaha Budidaya Purik}

Berdasarkan hasil pengamatan diketahui bahwa umur tanaman purik yang dibudidayakan responden penelitian antara umur 8 bulan sampai umur 7,5 tahun, dan sebagian besar $(75,5 \%)$ umur tanaman purik yang dibudidayakan adalah berumur 3 (tiga) tahun ke atas. Hasil wawancara dengan responden penelitian bahwa purik mulai dipanen daunnya ketika berumur 6 bulan, dan hasilnya lebih sedikit dibandingkan dengan purik yang dipanen pada umur 3 tahun, namun untuk produksi purik yang dipanen pada umur 3 (tiga) tahun atau lebih tidak terlalu berbeda (hampir sama).

\section{Pengaruh Jumlah Tenaga Kerja} (HOK) Terhadap Pendapatan Usaha Budidaya Purik

Tenaga kerja usaha budidaya purik dikelompokan menjadi dua, yakni tenaga kerja dari lingkungan keluarga dan tenaga kerja luar lingkungan keluarga. Dari hasil survei lapangan menunjukkan bahwa jumlah Hari Orang Kerja (HOK) masing-masing responden penelitian yang membudidayakan purik setiap bulan tidak jauh berbeda yakni rata-rata $30-32 \mathrm{HOK}$. Kondisi tersebut menyebabkan jumlah tenaga kerja tidak berpengaruh signifikan terhadap tingkat 
pendapatan (keuntungan) usaha budidaya purik. Kemudian penambahan jumlah tenaga kerja (HOK) justru akan menurunkan keuntungan usaha budidaya purik.

\section{Pengaruh Harga Bibit Purik Terhadap Pendapatan Usaha Budidaya Purik}

Bibit yang digunakan dalam usaha budidaya purik berasal dari sumber yakni bibit purik bersumber dari pembelian dan bibit purik dari tanaman sendiri. Total jumlah bibit bersumber pembelian sejumlah 31.500 bibit, dan total jumlah bibit sumber bibit sendiri sejumlah 45.420 bibit. Rata-rata harga bibit sumber pembelian sebesar Rp 2.600 /bibit, sedangkan rata-rata harga bibit sumber bibit sendiri (harga diperhitungkan) sebesar Rp 2.600.-, sama dengan rata-rata harga bibit purik sumber pembelian. Tidak adanya perbedaan antara harga bibit pembelian dengan harga bibit sumber sendiri menyebabkan harga bibit tidak berpengaruh signifikan terhadap pendapatan usaha budidaya purik.

Nilai koefisien regresi positif, menunjukkan bahwa dalam perhitungan ekonomi harga bibit purik masih bertambah, namun sebaiknya penggunaan bibit lebih banyak menggunakan bibit dari tanaman sendiri, sehingga penambahan harga bibit tersebut berdasarkan harga bibit diperhitungkan (biaya non tunai), dan penambahan harga bibit tidak berpengaruh atau mengurangi tingkat pendapatan (keuntungan) usaha budidaya petani.

\section{Pengaruh Input Produksi TerhadapPendapatan Usaha Budidaya Purik}

Input produksi dalam penelitian adalah biaya yang dikeluarkan untuk biaya sarana faktor produksi terdiri biaya pupuk, insektisida dan biaya sarana penunjang lainnya seperti ragak, terpal, karung goni, BBM dan lain-lain. Berdasarkan hasil wawancara dan pengamatan lapangan, penggunaan sarana input produksi seperti pupuk, insektisida dan sarana penunjang lainnya masih kurang efektif dan belum punya stadar (acuan) yang dijadikan pedoman, salah satunya penggunaan pupuk yang mana masing-responden penelitian tidak sama dalam penggunaan pupuk, demikian juga dengan sarana lainnya.

Penggunaan sarana input produksi tidak efektif dan efisien akan menimbulkan biaya input produksi menjadi besar, hal ini akan berpengaruh pada tingkat pendapatan (keuntungan) usaha budidaya purik. Hal ini sesuai teori ekonomi bertambahnya biaya produksi akan menurunkan tingkat pendapatan (keuntungan) suatu usaha. Sejalan pula dengan pendapat Ginting, dkk. (2013) pengaruh penggunaan input produksi dalam usaha tani ubi kayu, secara serempak penggunaan input produksi berpengaruh nyata terhadap produksi ubi kayu di daerah penelitian.

Pengaruh Upah HOK Terhadap Pendapatan Usaha Budidaya Purik

Ola dan Sukamto (2013) dalam teori ekonomi dijelaskan bahwa penambahan jumlah tenaga kerja hanya dapat dilakukan sampai pada titik 
tertentu. Penambahan jumlah tenaga kerja yang tidak terkendali atau melebihi titik tertentu dapat menurunkan tingkat produksi. Hal tersebut dijelaskan dengan hukum pertambahan hasil yang menurun (the law of diminishing return). Hukum ini menyatakan bahwa penambahan jumlah tenaga kerja hanya boleh dilakukan sampai produk fisik marjinal tenaga kerja (marginal physical product of labor) sama dengan nol. Ketika marginal physical product of labor sama dengan nol, penambahan jumlah tenaga kerja akan menyebabkan marginal physical product of labor menjadi negatif. Hal ini dapat dipahami, karena penambahan jumlah tenaga kerja atau hari orang kerja (HOK) akan menambah biaya input faktor produksi tenaga kerja. Jika penambahan tenaga kerja atau HOK tidak diimbangi dengan peningkatan penerimaan, maka penambahan biaya input faktor produksi tenaga kerja (HOK) akan menurunkan tingkat pendapatan (keuntungan) usaha budidaya purik.

\section{Pengaruh Dummy Terhadap Pendapatan Usaha Budidaya Purik}

Hasil observasi lapangan diketahui bahwa harga jual jenis daun kartom basah lebih rendah dari jenis daun remah kering, dan $95 \%$ responden penelitian menjual hasil produksi daun purik dalam bentuk daun remah kering. Artinya ada keseragaman jenis daun purik yang dijual oleh responden penelitian, dan hal ini menyebabkan variabel dummy (jenis daun purik yang dijual) tidak berpengaruh signifikan terhadap keuntungan usaha budidaya purik. Nilai koefisien negative, mengisyaratkan bahwa penjualan daun purik jenis basah akan menurunkan keuntungan usaha budidaya purik.

\section{KESIMPULAN}

1. Rata-rata dari 56 responden, setiap bulannya produksi purik (Mitragyna sp) sebesar $188 \mathrm{~kg}$. Pendapatan (keuntungan) yang diperoleh petani purik setiap produksi 1 (satu) kilogram purik sebesar Rp 10.658,maka setiap bulannya petani purik akan memperoleh pendapatan (keuntungan) sebesar Rp Rp 2.003.704,- atau dalam waktu setahun sebesar Rp 24.044.448,atau $\mathrm{Rp}$ 65.875/hari.

2. Nilai $\mathrm{R} / \mathrm{C}$ ratio sebesar 3,6 yang menunjukkan lebih besar dari 1 maka usaha budidaya tanaman purik (Mitragyna sp) di Desa Nanga Manday Kecamatan Bika Kabupaten Kapaus Hulu sanagt layak untuk dilaksanakan. Sederhananya keuntungan yang akan diterima besarnya 3,6 kali lipat atau hampir 4 kali lipat untuk 1 rupiah yang dikeluarkan.

3. Break Even Point atau titik impas pada usaha budidaya tanaman purik berdasarkan perhitungan menghasilkan BEP Harga sebesar Rp 1.231/kg dan BEP Produksi sebesar 15,66 Kg. Artinya, bila petani responden di Desa Nanga Manday Kecamatan Bika Kabupaten Kapuas Hulu menghasilkan produksi purik sebesar 15,66 Kg dengan harga jual 
Rp 1.231/kg maka usaha budidaya tanaman purik mengalami titik impas, yakni tidak mengalami kerugian atau tidak mendapatkan keuntungan.

4. Secara simultan (bersama-sama) X1, $\mathrm{X} 2, \mathrm{X} 3, \mathrm{X} 4, \mathrm{X} 5, \quad \mathrm{X} 6$ dan $\mathrm{D}$ berpengaruh signifikan terhadap pendapatan usaha budidaya purik (Mitragyna sp). Secara parsial (sendiri-sendiri) input produksi dan upah HOK berpengaruh signifikan terhadap pendapatan usaha budidaya bratom (Mitragyna sp). Tingkat R Square sebesar $0,986 \quad(98 \%)$. Persamaan regresi:

$$
\hat{Y}=1,012-0,021 X_{1}+0,000 X_{2}-0,0004 X_{3}+0,006 X_{4}-1,090 X_{5}-1,107 X_{6}-0,011 D \text {. }
$$

\section{SARAN}

1. Budidaya purik merupakan salah satu sumber penghidupan masyarakat di Kabupaten Kapuas Hulu. Seharusnya pemerintah khususnya Badan Narkotika Nasional (BNN) tidak melarang kegiatan jual beli purik, karena purik dapat memberikan keuntungan yang tinggi dan meningkatkan kesejahteraan masyarakat serta masyarakat tidak merambah hutan.

2. Sebaiknya masyarakat di Desa Nanga Manday membentuk sebuah asosiasi petani purik atau koperasi sehingga dapat memberikan kontribusi untuk pendapatan daerah.

\section{DAFTAR PUSTAKA}

Anita, Aminuyati, Ulfah, Maria. 2019. Analisis Pendapatan Petani Kratom dalam Membantu Pembiayaan Pendidikan Anak Desa Sungai Uluk Palin. Jurnal Pendidikan dan Pembelajaran Khatulistiwa Vol. 8 (4) : $1-8$.

Ginting GF, Tobing HML dan Sebayang T. 2013. Analisis Optimasi Penggunaan Input Produksi Pada Usahatani Ubi Kayu. Jurnal on Social Economic of Agriculture and Agribusiness. Vol. $2(3): 1-11$.

Imelda. 2012. Analisis Risiko Pada Usaha Penangkapan Kepiting
Bakau di Kecamatan Sungai Kunyit Kabupaten Pontianak. Jurnal Sosial Ekonomi Pertanian. Vol. 1 (1) : 75 - 95.

Juliansyah H, Riyono A. 2018. Pengaruh Produksi, Luas Lahan dan Tingkat Pendidikan Terhadap Pendapatan Petani Karet di Desa Bukit Hagu Kecamatan Lhoksukon Kabupaten Aceh Utara. Jurnal Ekonomi Pertanian Unimal Vol. 1 (2) : 65 - 72.

Junaidi. 2016. Analisis Pendapatan Usaha Tani Kelapa Sawit di Desa Panton Pange Kecamatan Tripa Makmur Kabupaten Nagan Raya. [Skripsi]

http://repository.utu.ac.id/ 1449/1/BAB\%20I-V.pdf. diakses, tanggal 16 Maret 2020.

Kumara I. 2019. Desa-Desa yang Telah Melaporkan Jumlah Petani Purik di Wilayahnya (Data s/d 12 Agustus 2019). Kabupaten Kapuas Hulu: Badan Perencanaan Pembangunan Daerah.

Monografi Desa Nanga Manday. 2018.

Ola FGPR dan Sukamto A. 2013. Pendapatan dan Fungsi Produksi Jagung (Studi Kasus pada Usaha Tani Jagung di Pedukuhan Sawah, Monggol, Saptosari, Gunungkidul). Jurnal Universitas 
Atma Jaya Yogyakarta, Vol. 3 (1) $: 1-15$.

Portal Informasi Indonesia. 2020. Kratom, Daun Dolar yang Masih Kontroversi.

https://www.indonesia.go.id/raga $\mathrm{m} /$ pariwisata/ekonomi/kratomdaun-dolar yang-masihkontroversi. Diakses, tanggal 18 $03-2020$.

Rahardi F. 2003. Agribisnis Tanaman Buah. Jakarta : Penebar Swadaya. www. Respositori.uinaluddin.ac.id. Diakses, tanggal 20 $-11-2019$.

Republik Indonesia. 2003. UndangUndang Republik Indonesia No.13 Tahun 2003 Tentang Ketenagakerjaan. Jakarta : Sekretariat Negara.

Slovin MJ. (1960). Sampling. New York: Simon and Schuster Inc.

Soekartawi. 1994. Teori Ekonomi Produksi dengan Pokok Bahasan Analisis Fungsi Produksi CobbDouglas. Rajawali Jakarta.

Soekartawi. 2002. Analisis Usahatani. Jakarta: Universitas Indonesia.
Sridianto A. 2016. Analisis Pendapatan Petani Tomat di Desa Kanreapi Kecamatan Tombolo Pao Kabupaten Gowa. [Skripsi] http://repositori.uinalauddin.ac.id/2337/. Diakses, tanggal $31-10-2019$.

Suratman YYA. 2015. Kontribusi Tenaga Kerja dalam Keluarga terhadap Pendapatan Usahatani Terong ( Solanum melongena L.) Di Kelurahan Landasan Ulin Utara Kecamatan Liang Anggang Kota Banjarbaru. Ziraa'ah Vol. 40 (3) : $218-225$.

Teken, I. B. 1965. Teknik Sampling. Jakarta: PT. Gramedia Pustaka Utama.

Upah Minimum Kabupaten/Kota (UMK) Kalimantan Barat 2020.

Wonda M, Tomayahu E. 2016. Pendapatan Usahatani Tanaman Kakao (Teobroma kakao) di Kelurahan Hinekombe, Distrik Waibu, Kabupaten Jayapura. Agrologia Vol. 5 (1) : 30 - 35 